\title{
THE ELECTRONIC ENVIRONMENT AND THE PROTECTION OF INTELLECTUAL PROPERTY
}

\author{
Miroslav Andonovski ${ }^{388}$ \\ Karolina Shukuroska ${ }^{389}$ \\ Marija Midovska Petkoska ${ }^{390}$
}

https://doi.org/10.31410/itema.2018.1132

\begin{abstract}
The term intellectual property indicates special specific rights that have the authors, inventors and other holders of intellectual property rights. Intellectual property is not specifically material property over an object; it is a right that is a set of authorizations that the legal system of the state recognizes to the holders of intellectual property rights.

The revolution in information technology and the increasing number of inventors, the impact and significance of innovation along with globalization, will bring intellectual property at the centre of attention. Sometimes a subsidiary area, but today it is an important factor in the strategic planning of companies and also a key factor in any state policy.

New products in the markets attract consumers. They are also in the hit by competition who wants to make an identical or similar product. This can be done in various ways: using economies of scale, expanding access to markets, accessing cheaper raw materials, etc. All this is in order to make the same or similar products at a lower price and make pressure on the inventor of the original product or service. Such circumstances may lead to the downfall of the inventor's business of the original product because he has made significant investments in the creation and development of the new product, and competitors only use the results of such creativity and / or inventiveness.

That is why especially small and medium-sized enterprises have to think to protect their creative and innovative work through the intellectual property system. The system for protection of intellectual property rights provides exclusive rights in the use of inventions, designs, brands, literary and artistic works. Through the system of intellectual property protection and the provision of ownership of a particular invention or creative work, the possibility of copying and imitating innovative works by the competition is limited in an effective manner. We will try to prove it by elaborating the types of protection of the intellectual property from the aspect of the subject of protection, that is the protection of copyright and related rights and the protection of inventions-patents.
\end{abstract}

Keywords: intellectual property, rights, protection, patent

\section{INTRODUCTION}

Intellectual property can be divided into two main branches according to the subject of protection: copyright and related rights and industrial property.

\footnotetext{
${ }^{388}$ University “Ss. KlimentOhridski”-Bitola, Faculty of economics-Prilep, Macedonia

${ }^{389}$ Ministry of finance, Property and Legal Affairs Office, Regional office for carrying out first-instance procedure - Prilep, Macedonia

${ }^{390}$ University “Ss. Kliment Ohridski”-Bitola, Faculty of economics-Prilep, Macedonia
} 
Copyrights and related rights include: cultural, artistic and literary works. Computer software and compilation of data can be also categorized as copyright in some countries.

\section{Industrial property includes:}

- innovative products and procedures through patent protection,

- creative designs through the protection of industrial design,

- brands through the protection of trademarks,

- microchips by protecting the design of the layout of the ingress circuit,

- marks of goods of certain quality through geographical origin with geographical indication,

- trade secrets through the protection of secret information with commercial value.

These two main categories actually determine the ways of protecting intellectual property. Today, the absolute dominant role in the shaping of intellectual property rights belongs to large corporations owned by large portfolios of copyrights, patents, and brand names. [1]

The technological development and the emergence of globalization contribute to the issue of intellectual property rights and its protection. The development of intellectual property rights is predestined by the use of new technologies. Information technology and the Internet as a global communications network enable the development of communication systems on a global scale. This will enable a new way of using products created by the human mind such as: electronic reading of books, newspapers, watching movies.

New technology brings new risks. Abuse can cause major damages to the holders of the intellectual property rights, on the companies and on the society as a whole. The Internet space cannot be restricted. Computer is an asset through which can be violating the intellectual property from unauthorized users. It may be subject of attack because it has stored databases. Unauthorized use of databases and other information in digital form as well as other Internet content represents an illegal activity that is a big risk for large companies like banks, state bodies and often for the citizens.

\section{THE SIGNIFICANCE OF THE PROTECTION OF INTELLECTUAL PROPERTY RIGHTS}

Today, the issue for protection of intellectual property rights is of paramount importance and is one of the conditions for the development of the economy. High-tech crime in the computer area is a form of international crime. International cooperation is required for successful fight against this type of crime. The cooperation should be between the competent institutions through joint action, information exchange and risk assessment.

Developed countries will realize that their current and future comparative advantages depend on the ability to dominate industry branches with high participation in innovation, which will require them to take repressive measures against those countries that tolerate disproportionate intellectual property on the domestic market property. [2]

Computer crime is a new type of crime and it is developing very quickly. It is necessary to constantly monitor its forms and constantly improve the regulation in order to create an appropriate legal framework for the protection of intellectual property holders.

States that will provide good protection of intellectual property rights encourage foreign investors to invest in new ventures. Well-protected intellectual property is a new value not only 
in the economy, but also in the society as a whole. The economic costs of inadequate legal protection of intellectual property rights (protection that is inadequate from the aspect of social and private interest) is a loss of interest of foreign companies to innovate in a country where there is no adequate protection, a potential loss of the initiative for inventory operations, foreign companies to transfer top technology and reduce foreign direct investment. [3]

Intellectual property is a key element in electronic commerce. Electronic commerce often involves the sale of products and services that are based on intellectual property and licensing them. Intellectual property is also important because value-added goods that are traded on the Internet must be protected by technological security systems and intellectual property laws. Otherwise, they can be stolen or piracy and thus whole businesses fail.

The significance of intellectual property in electronic trade can be seen from another angle. Namely, intellectual property is important to put into operation the electronic commerce. The systems that enable functioning of the Internet, software networks, routers and others, very often are protected with intellectual property rights. Trademarks are an important part of the business in the electronic trade, because branding, consumer recognition, the basic elements of web based businesses are protected through the trademark protection system and anti-unfair competition laws.

Internet-oriented business and e-commerce can be based on product or licensing patents. The development of high-tech products would be impossible if each company would have to independently develop all the technological aspects of its products. Many large companies, but also small and medium-sized enterprises, depend on that joint sharing activity through licensing. It can be concluded that the economy of electronic commerce depends on the way of sharing new technologies. Evaluating the business of electronic commerce is always related to whether its intellectual property rights are protected.

\section{PROTECTION OF COPYRIGHT IN THE ELECTRONIC ENVIRONMENT}

Copyrights are set of authorizations for the author of the copyright work. They are authorizations that on the basis of legal norms are recognized by the author. Copyrights that are recognized by the author are actually original intellectual creations.

Copyright in the objective sense is a set of legal norms that regulate social relations in relation to the creation and exploitation of copyright works, that is, works in the field of literature, science and art. [4]

In legislation for protection of copyright there is not some sort of unified list of rights that are protected, but basically laws on copyright protection of national level predict copyright in the following fields: literary works, musical works, artistic works, maps and technical drawings, film works, computer programs and multimedia products.

Copyrights are acquired at the time of creating the work. In fact, it is an original picture of the author's idea. That is why at the copyright the subject of assessment is originality, and it is given separately for each particular case.

Apart from the author, the copyright should include the term "user of rights" and should be considered separately from the copyrights. It can be said that the copyright user is an entity that translates copyright into a product-goods (a copy of a book) or a service (displaying a movie, 
broadcasting music) and in such a form is offered to the audience and consumers. Observed from this aspect, copyright is a right that regulates the relations between authors and users of the work, whereby the audience and consumers are outside the copyright. [5]

The use of copyright as recordings, shows or performances is the basis of their business activities for many companies. Publishing houses, libraries, and radio stations operate on the basis of the use of these rights. Other copyright companies use them occasionally and are in the function of improving their publications.

Companies-entities that are copyright users when carrying out their business activities have an obligation to understand the copyright system and its protection because they use protected copyrights. Today, this primarily relates to software developers, creators of websites, advertising agencies, publishing houses, television channels and so on.

Apart from the field of copyright, a new field of copyright-related rights has been developed in the last few decades. These are the so-called related rights that are related to copyright works and often have similar powers that are more limited and shorter. This primarily refers to:

- performers-actors and musicians in their performances,

- producers of music recordings (albums, compact discs) on their recordings

- radio-diffusion organizations on their radio and television programs.

The distinction between related rights and copyright is reflected in the fact that related rights belong to carriers that are a kind of intermediary in the production, filing or diffusion of works. The aforementioned categories of related rights are derived from the process of intellectual creation of the copyright work; they actually give their support to the authors in what constitutes communication of the author's work with the public. These are situations when the musician performs the musical work written by the composer, the actor plays a role in a play written by a dramatic author. It should be noted that the use of these copyrights is always related to the permission of the right holder. In economic terms [6] it always avoids the payment of royalties or fees for obtaining such a license.

In order to ensure protection of intellectual property rights it is necessary to implement a procedure for their registration. In contrast, copyrights are not subject to official procedures. According to international conventions (for example, the Berne Convention for the Protection of Literary and Artistic Works), literary and artistic works in the countries signatories to this Convention are protected without the implementation of special procedures. There is no international copyright registration system. This issue is left to the national states. Today, a number of countries have their own national agencies or copyright bodies where copyright works are registered. Registration of copyrights under national laws of some countries is considered to be fundamental evidence before the courts in disputes concerning copyright.

Authors of copyrighted works have the exclusive right to use it or authorize to other persons to use it under pre-agreed terms. But they can also prohibit its use. This means that the authors have exclusive rights to their works. The author may permit or prohibit on his work to be performed:

- production-in different forms,

- initial distribution to the public,

- shaping samples to the public,

- publicly performing a drama or a musical work, 
- discs in the form of discs or video tapes,

- broadcasting via radio, by satellite (satellite), cable,

- translation into other languages, or adaptation-an example of a novel for the scenario.

Failure to admit the decision of the creator of the work to allow or prohibit the use of his work, as well as in the case where it is used without his permission is often subject to administrative and judicial procedures.

A number of copyright should distribute an activity in order to be able to reach the public. This is often associated with a large financial investment (publications, films). That is why the authors often transfer the rights to their works to intermediaries or companies that can do it best and place them on the markets, in exchange for payment. This type of payment is made according to the actual use of the work and is called royalties. Fees for the transfer of copyright to other entities are in the category of economic rights and they have time limits. It is usually 50 years after the death of the author. But some national states can determine a longer term for a certain kind of copyright. Through the economic rights of the creators and their heirs, they are allowed to have financial gain over a certain period of time, which is not the basic kind of satisfaction for the author.

Besides economic rights, there are moral rights. Through the moral rights the author may seek the recognition of authorship of his work, the right to resist any changes that may harm his reputation and the like. Moral rights are related to the author himself, with his personality. They are not transmitted to others even after the death of the author and are not time-limited.

The growing popularity of multimedia productions which include more type of copyrighted works including computer software has need to provide licenses to use for various types of copyright. This is a fairly complicated process. Because of this there is a need for association of individual types in one organization called One-stop-shops. These organizations represent a central system through which appropriate authorizations can be obtained in a faster and easier way. The provision of licenses for the use of copyright and related rights through relevant associations for the collective exercise of rights of users always saves time and money.

Regulating copyright protection and the conditions under which other entities are able to use them is extremely important to both authors and anyone who wants to use copyrighted works.

After the adoption of the first copyright laws, the issue of international copyright protection appears. Foreign authors and their works are not enjoying legal protection, but it depended on the existence of bilateral agreements between the country of his nationality and author country in which the author appeals procedure. Such contracts were scarce and provided legal protection only to nationals of countries that had concluded bilateral agreements. In addition, these agreements usually regulated other disputes between contracting parties, and copyright rights shared the legal fate of other legal relationships. With the cancellation of contracts or the expiration of the time for which the contract was concluded, foreign authors were left without legal protection. [7]

Previously stated problems and questions will impose the need for this matter to be regulated by international documents.

The oldest and best known copyright law is the Berne Convention of 1886 for the Protection of Literary and Artistic Works. [8] 
It has been signed by ten European countries in order to protect written and artistic works. By 2016, 164 States will accede to this Convention. Three principles have been established with the Bern Convention:

- The principle of national treatment - according to which the signatory countries of the Bern Convention are obliged to provide the citizens of the signatory countries with the same rights that the Law on Copyright gives their citizens,

- Independent protection - this principle creates an obligation for each State party to the Berne Convention to ensure the protection of works by foreign authors in the same way as the works of domestic authors are protected, even if the work of a foreign author is not protected by the copyright law of the country in which it was created.

- Automatic protection of copyright works-under which the States Parties to the Berne Convention are prohibited from making any conditions on foreign authors who are nationals of the signatory States of this Convention in order to secure the protection of their copyrights. By 1952 two of the biggest they states, the US and the USSR signed the Berne Convention. On a UNESCO proposal in 1952, a new convention will be created - the Universal Convention on Autocratic Rights [9] as a replacement for the Bern Convention, which will be signed by both the major world powers US and USSR.

The development of new technologies will impose the need to protect the recorded works. In 1961, the member countries of the World Trade Organization will sign the Rome Convention for the Protection of Producers, and Producers of Phonograms. It should be noted that with the Bern and the Rome Convention no sanctions have been provided for the member states in case some of the prescribed principles are not respected.

For copyright and particularly computer programs and computer databases was adopted TRIPS agreement of $-A$ contract Trade Related Aspects of Intellectual Property Rights. This Agreement provides effective sanctions for member states that do not provide effective protection of copyrights within their own country, as well as mechanisms by which the undertaken obligations with the Agreement will be met.

In 2007, the ACTA Agreement was signed [10], in order to prevent the falsification of copyright works. The ACTA agreement provides officials with no prior notice to explore unauthorized downloaded music files and other content on the Internet. At the same time the Internet operators are mandated to provide information to the official person in respect of violators of laws for abuse on the Internet. Here we consider it is necessary to point out that there are opponents of the ACTA agreement, under which the agreement violates the personal rights of Internet users.

\section{PATENTS IN ELECTRONIC COMMERCE}

Inventions are the basis for the development of human civilization. Historically, from a steam engine to computers and other technologies, new discoveries are the greatest contribution that inventors have captured humanity. People with vision, entire life and often their own assets devoted to research that verified after their deaths, with most results of their work to benefit future generations.

But today the situation is quite different. A number of companies form scientific teams allocate huge financial resources in order for scientists-researchers to be motivated to create innovations that lead to company development, and often progress on the whole of humanity. 
The invention is a new solution to the technical problem, while the patent is a universally accepted legal form for the protection of the invention. [11]

The patent is exclusively a territorial and time-limited monopoly right established for the benefit of the inventor. The patent is exclusive right which is recognized to protect the invention. A patent holder may prevent others from producing, using or selling a patented invention if they do not have permission to do so. Regarding the patent there is a theory of incentives under which society-with the approval of the patent stimulates innovation, which is an important factor for global economic growth, but also an important element in competitive relations. According to the theory of reward, the principle of equity requires that every useful service given to society be rewarded. [12] In many countries, the invention is often described as a solution to a technical problem. Regardless of whether the problem is old or new, the solution must be new so that it can be considered an invention. What already exists in nature, what everyone can discover cannot be considered an invention.

In order the invention to be patented, it should go through an appropriate procedure that ultimately will provide adequate legal protection. In doing so, the invention must meet the conditions in order to obtain the status of a patent.

The invention must be new - it should be a new solution to the technical problem. Novelty is considered to exist if there is any difference between the invention and the existing knowledge and state of the technique.

In addition to novelties as the first requirement to be fulfilled, the second requirement that the invention should fulfill is the so-called inventive contribution. The condition for the inventive contribution is considered fulfilled if the invention does not arise from the known state of the art technique for the expert in a particular area, but it is the result of the individual labor and creativity of the inventor. Inventiveness is essentially a matter of matter and it is determined on a case-by-case basis in a concrete manner, requiring a high level of inventiveness. Certain inventions that do not contain a higher level of inventiveness and do not qualify for patentability i.e. are not patentable, can be placed in the category of useful models-small patents. The third requirement that should be met in order for the invention to be patented is its applicability in the industry or in some economic activity. This means that the invention should go through the practical form of check whether it's a device, a new material, or a new process in the industry. It should be noted that the requirement of applicability is provided in all national legislation.

The procedure and conditions for patenting the invention are prescribed by international legal documents such as the Paris Convention of 1883 and the laws of each national state. All these regulations provide for the existence of an appropriate national registration body or patent office.

An appropriate procedure is being conducted in front of this competent authority in several phases: submission of the application, formal examination of the application, publication of the application, substantive examination and adoption of a decision for accepting or rejecting the patent application. Patent documents contain a large number of information that can be useful for companies, especially when planning their business. Special significance for small and medium enterprises because they with their direct application can save unnecessary costs for research, to explore new technologies and implement them in Mena, or through the patent can provide ready-made solutions to their technical problems. 
On the other hand, patent information from companies can help them create new business partnerships, communicate with new suppliers.

It is undisputed that the invention cannot find its adequate application if it is not patented. The patent from an economic point of view in the time period foreseen for use-20 years, gives the entity a better image of the company, an opportunity to license or sell, a better position on the market. Otherwise, someone else can patent the invention, or be used by competitors.

Although at the national level, the purpose of the patent protection proceedings is very similar between the states, especially if the fundamental principles (national treatment, assimilation and minimum rights) of the Paris Convention for the protection of intellectual property are taken into account, its specifics. Therefore, the protection of inventions, especially in the Republic of Macedonia, is left to be the object of research for some other scientific work.

\section{CONCLUSION}

The revolution in technology development, especially in information technology and the increasing number of inventors, the impact and importance of innovation along globalization, contributed intellectual property to be found in the center of attention.

That is why especially small and medium-sized enterprises have to think to protect their creative and innovative work through the intellectual property system. The system for protection of intellectual property rights provides exclusive rights in the use of inventions, designs, brands, literary and artistic works.

According to the subject of protection, intellectual property can be divided into two main branches: copyright and related rights and industrial property.

Technological development and the emergence of globalization will contribute to the issue of intellectual property and its protection to be given greater importance.

Intellectual property rights are one of the conditions for development of economy. The question of their protection is extremely important today.

Computer crime as a new form of crime and it is developing very fast. It requires constant monitoring of its forms and continuous improvement of the regulation in order to create an appropriate legal framework for the protection of the holders of the rights of intellectual property.

Countries that will provide good protection of intellectual property encourage foreign and investitures for new ventures. Well-protected intellectual property is a new value not only in the economy, but also in the society as a whole.

Intellectual property is a key element of electronic commerce. This is because electronic commerce often involves the sale of products and services that are based on intellectual property and licensing them. The importance of intellectual property in electronic commerce can be seen from the aspect of its putting into operation. Without the innovations in information technology, the functioning of electronic commerce would be inconceivable. 
Evaluation of the business of electronic commerce is always related to whether his rights of intellectual property are protected, because the value of businesses in e-commerce is usually in the form of intellectual property.

The regulation of copyright protection and the conditions under which other entities can use them is extremely important to both the authors themselves and anyone who wishes to use copyrighted works.

Inventions are again the basis for the development of human civilization. The invention is a new solution for technical and problem solving, while the patent is a universally accepted legal form for the protection of the invention. The patent is exclusively a territorial and time-limited monopoly right established for the benefit of the inventor. A patent is an exclusive right that is recognized to protect the invention. A patent holder may prevent others from producing, using or selling a patented invention if they do not have permission to do so.

\section{REFERENCES}

[1] Slobodan.M.Marković, Pravo intelektualne svojine i informacijsko društvo, Sluzbeni glasnik 2014, str.275

[2] Vesna Bisasarović, Intelektualna svojina, Pravni fakultet Univerziteta u Beogradu, 2011, p.31.

[3] Bineley.M.Intellectual Property Rights, a Strategy of Developing Nations, Toronto, 1991 p.5

[4] Katarina Damjanović i Vladimir Marić, Inetektualna svojina, Pravni fakultet Univerziteta u Beogradu, Sluzbeni glasnik, Beograd, 2012, p.39.

[5] Slobodan.M.Marković, Pravo intelektualne svojine i informacijsko društvo, Sluzbeni glasnik 2014, str. 114.

[6] Precisely, the economic sense, the benefit, the profit, is at the core of the protection of intellectual property rights. If there is no economic benefit from the copyright work, which is the meaning of his protection. Of course, here we neglect the moral moment in the protection of rights.

[7] Vesna Bisarović, Intelektualna svojina, Pravni fakultet Univerziteta u Beogradu, 2011, p. 53-54

[8] Bern Convention on the Protection of Literary and Artistic Works, 1886.

[9] The Univesal Copyright Convention, 1952

[10] Anti-Counterfeiting Trade Agreement, 2007.

[11] Vesna Bisarović, Intelektualna svojina, industrijska svojina i autorsko pravo, Pravni fakultet Univerziteta u Beogradu, Centar za izdavaštvo i informisanje, Beograd 2011, p. 66

[12] A. Veron, Law of Industrial Property, Zagreb, 1979, p.68 